\title{
Eastern North Pacific Hurricane Season of 2008
}

\author{
ERIC S. BLAKE AND RICHARD J. PASCH \\ NOAA/NWS/NCEP, National Hurricane Center, Miami, Florida
}

(Manuscript received 10 June 2009, in final form 29 September 2009)

\begin{abstract}
The hurricane season of 2008 in the eastern North Pacific basin is summarized, and the individual tropical cyclones are described. Official track and intensity forecasts of these cyclones are also evaluated. The 2008 eastern North Pacific season was relatively quiet, with overall activity at about $75 \%$ of the long-term median. A total of 16 tropical storms formed, of which 7 became hurricanes and 2 became major hurricanes. One hurricane, one tropical storm, and two tropical depressions made landfall in Mexico, causing eight direct deaths in that country along with significant property damage. In addition, Tropical Storm Alma was the first tropical cyclone on record to make landfall along the Pacific coast of Nicaragua. On average, the official track forecasts in the eastern Pacific for 2008 were quite skillful and set records for accuracy from 1 to 3 days. However, no appreciable improvement in mean intensity forecast skill was noted.
\end{abstract}

\section{Overview}

As in the previous year, tropical cyclone activity in the eastern North Pacific basin in 2008 was below average, with the season continuing the relative quietness in this basin that has prevailed since 1995 . Indeed, 10 of the past 14 hurricane seasons have seen below-average activity in the eastern North Pacific. In total, 16 tropical storms occurred in 2008, of which 7 became hurricanes and 2 became major hurricanes (Fig. 1). Although the number of tropical storms was near the long-term average of 15 , the numbers of hurricanes and major hurricanes (category 3 or higher on the Saffir-Simpson hurricane scale; Simpson 1974) were below the longterm averages of 9 and 4, respectively. Two tropical depressions that did not strengthen into tropical storms also formed during the season.

Another metric to gauge the overall activity of a season is the accumulated cyclone energy (ACE) index, which is defined as the sum of the squares of the maximum wind speed at 6-h intervals for all tropical storms and hurricanes. The ACE index for 2008 was $82.2 \times$ $10^{4} \mathrm{kt}^{2}$, or about $75 \%$ of the long-term (1971-2005) median value, placing the 2008 season in the belownormal tercile of activity. One hurricane (Norbert), two

Corresponding author address: Eric S. Blake, National Hurricane Center, 11691 SW 17th St., Miami, FL 33165.

E-mail: eric.s.blake@noaa.gov tropical storms (Alma and Julio) and two tropical depressions (Five-E and Lowell) made landfall this season. All of these landfalls occurred in Mexico, except for Alma's, which occurred in Nicaragua. Notably, Alma is the first eastern North Pacific basin tropical storm or hurricane to make landfall along the Pacific coast of Central America since records began in 1949.

The 2008 season started in late May, with Alma forming on 29 May, the long-term median genesis date of the first eastern Pacific tropical storm. The early portion of the season was active, with four hurricanes observed before the end of July. However, only three more hurricanes formed during the remainder of the season. In fact, September, typically one of the busiest months of the season, only had two weak tropical cyclones and recorded the lowest September ACE value since reliable records began in 1971. October had a renewed period of activity, highlighted by the development of Norbert, the first October major hurricane since Kenna of 2002. The season closed with the development of Polo in early November, one of the lowest-latitude formations ever observed in the eastern North Pacific.

The below-average activity observed during 2008 appears to be primarily related to the 2007-08 La Niña. Although the sea surface temperature (SST) anomalies dissipated during the early summer, atmospheric anomalies more typical of a La Niña circulation persisted over the eastern Pacific (Peterson and Baringer 2009). Indeed, strong easterly wind shear was present during much of 

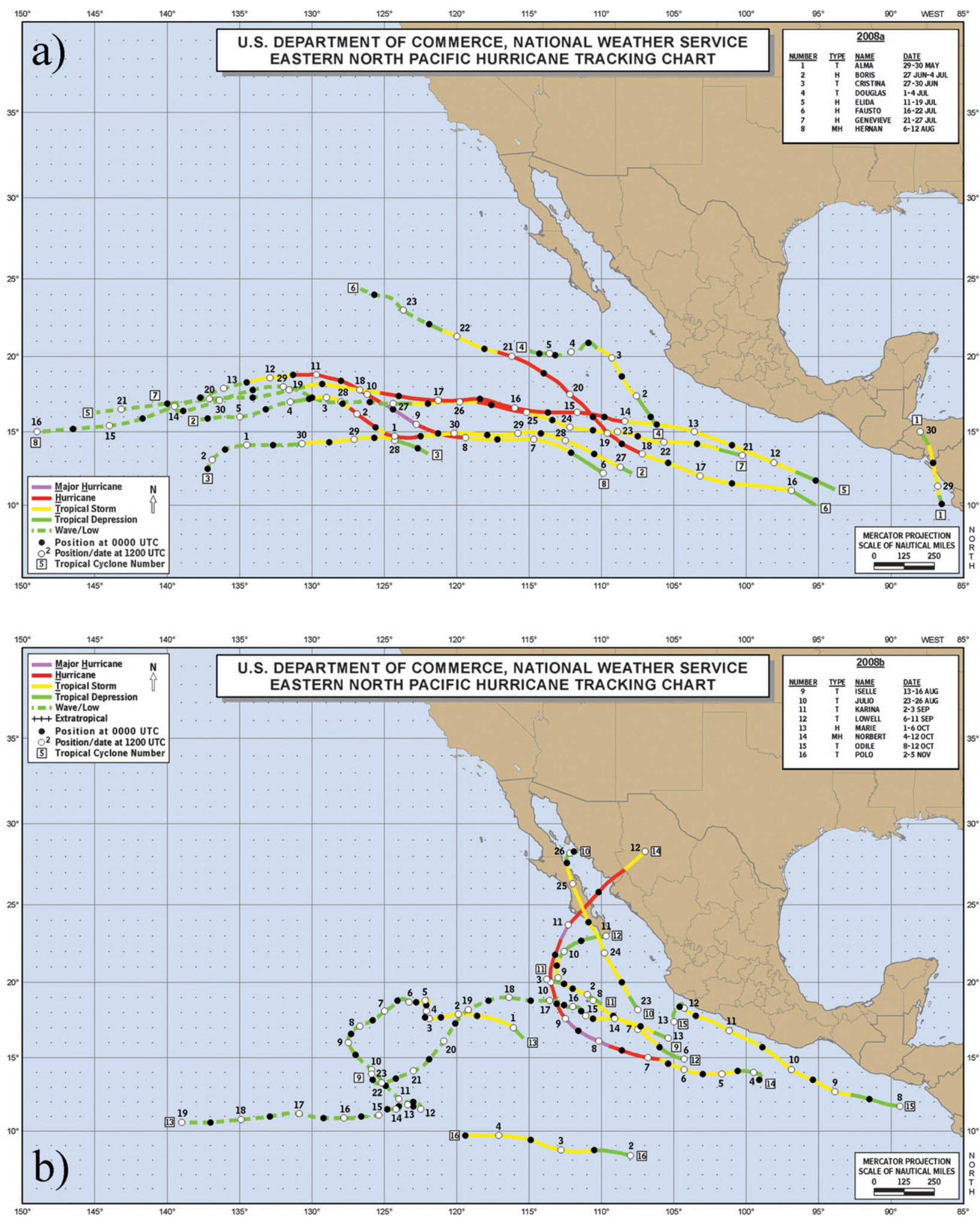

FIG. 1. (a) Track chart of the first eight eastern North Pacific tropical storms and hurricanes of 2008. (b) Track chart of the final eight eastern North Pacific tropical storms and hurricanes of 2008. 


\section{July-October 2008 \\ 200-850-hPa Vertical Wind Shear \\ Total}

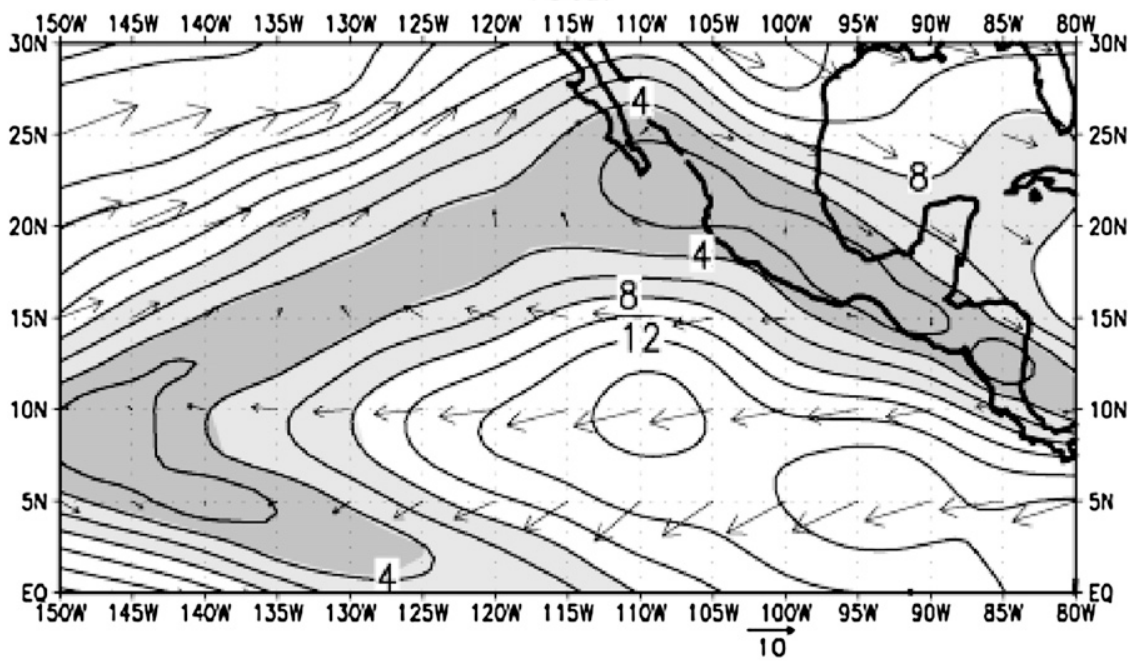

Anomaly

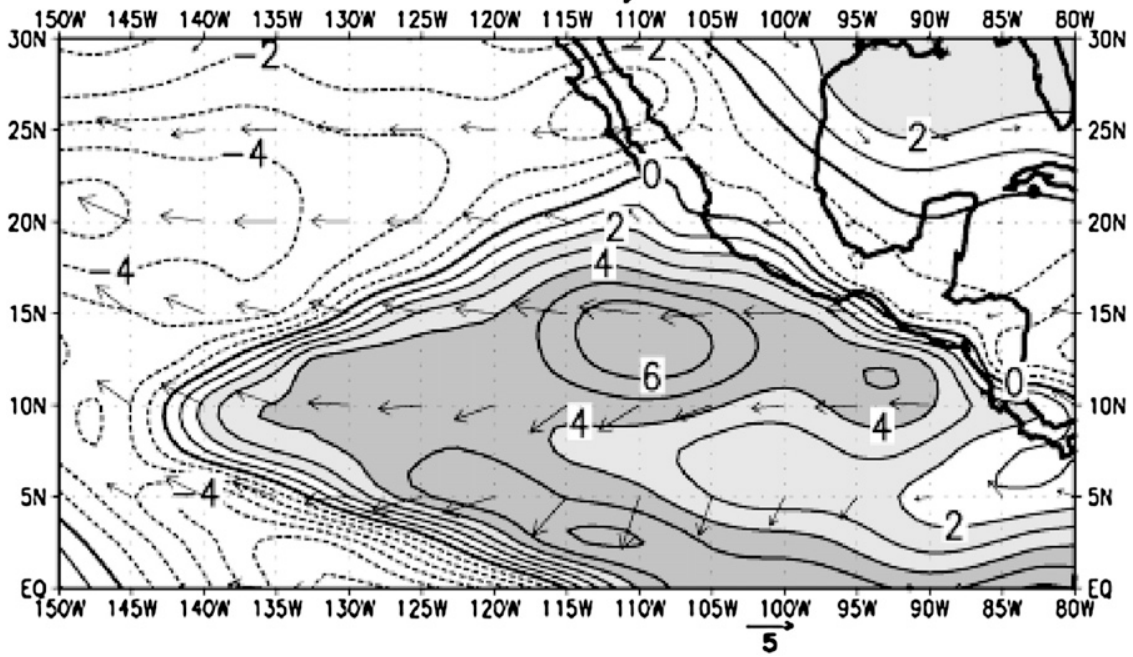

FIG. 2. July-October 2008 850-200-hPa vertical wind shear (top) magnitude and vectors and (bottom) anomalies in $\mathrm{m} \mathrm{s}^{-1}$. Anomalies represent departures from the 1971-2000 base period monthly means, computed from the NCEP-NCAR reanalysis dataset.

the season (Fig. 2), which kept many of the tropical storms from intensifying as much or as quickly as is typical. Overall SSTs in the basin were near the longterm average, though cooler than in most recent years (not shown). In the eastern North Pacific, however, SSTs do not have as strong of a relationship with overall tropical cyclone (TC) activity as they do the Atlantic basin.

One unusual feature of the 2008 season was the high number of tropical cyclones that originated from tropical waves that had already spawned tropical cyclones in the Atlantic basin. The formations of Julio, Katrina,
Lowell, and Marie can all be traced back, in part or exclusively, to waves that had previously generated Atlantic TCs Fay, Gustav, Hanna, and Kyle, respectively. Although this phenomenon has been observed previously (e.g., Kiko of 2007; Avila and Rhome 2009), the large number of these occurrences in 2008 is notable. In addition, the remnants of Alma also played a role in the development of Atlantic Tropical Storm Arthur in late May.

Summaries of the life cycle of each of the 2008 season's tropical cyclones are provided in section 2. Section 3 provides verification statistics on official National Hurricane Center (NHC) forecasts. 
TABLE 1. Eastern North Pacific tropical storms and hurricanes of 2008.

\begin{tabular}{|c|c|c|c|c|c|}
\hline Name & Class* & Dates** & $\begin{array}{c}\text { Max } \\
\text { 1-min } \\
\text { wind (kt) }\end{array}$ & $\begin{array}{c}\text { Min sea } \\
\text { level } \\
\text { pressure }(\mathrm{mb})\end{array}$ & $\begin{array}{l}\text { Direct } \\
\text { deaths }\end{array}$ \\
\hline Alma & TS & 29-30 May & 55 & 994 & 2 \\
\hline Boris & $\mathrm{H}$ & 27 Jun-4 Jul & 70 & 985 & \\
\hline Cristina & TS & 27-30 Jun & 45 & 1000 & \\
\hline Douglas & TS & 1-4 Jul & 35 & 1003 & \\
\hline Elida & $\mathrm{H}$ & 11-19 Jul & 90 & 970 & \\
\hline Fausto & $\mathrm{H}$ & 16-22 Jul & 80 & 977 & \\
\hline Genevieve & $\mathrm{H}$ & 21-27 Jul & 65 & 987 & \\
\hline Hernan & MH & 6-12 Aug & 105 & 956 & \\
\hline Iselle & TS & 13-16 Aug & 45 & 999 & \\
\hline Julio & TS & 23-26 Aug & 54 & 998 & 1 \\
\hline Karina & TS & 2-3 Sep & 35 & 1000 & \\
\hline Lowell & TS & 6-11 Sep & 45 & 998 & \\
\hline Marie & $\mathrm{H}$ & $1-6$ Oct & 70 & 984 & \\
\hline Norbert & MH & 4-12 Oct & 115 & 945 & 5 \\
\hline Odile & TS & $8-12$ Oct & 50 & 997 & \\
\hline Polo & TS & $2-5 \mathrm{Nov}$ & 40 & 1003 & \\
\hline
\end{tabular}

* $\mathrm{TS}=$ tropical storm, wind speed 34-63 kt (17-32 $\left.\mathrm{m} \mathrm{s}^{-1}\right) ; \mathrm{H}=$ hurricane, wind speed $64 \mathrm{kt}\left(33 \mathrm{~m} \mathrm{~s}^{-1}\right)$ or higher; $\mathrm{MH}=$ major hurricane, hurricane with maximum winds $96 \mathrm{kt}\left(49 \mathrm{~m} \mathrm{~s}^{-1}\right)$ or higher.

** Dates are based on UTC time and include the tropical depression stage, but exclude the remnant low stage.

\section{Tropical cyclone summaries}

The individual cyclone summaries that follow are based on NHC poststorm meteorological analyses of a wide variety of (often contradictory) data described below. These analyses result in the creation of a best-track database for each cyclone, consisting of 6-hourly representative estimates of the cyclone's center position, maximum sustained (1-min average) surface $(10 \mathrm{~m})$ wind, minimum sea level pressure, and maximum extent of 34 , 50 , and $64 \mathrm{kt}$ winds in each of four quadrants around the cyclone's center. The best track identifies a system as a tropical cyclone at a particular time if NHC determines that it satisfies the following definition: "a warm-core, non-frontal synoptic scale cyclone, originating over tropical or subtropical waters with organized deep convection and a closed surface wind circulation about a well-defined center" (Office of the Federal Coordinator for Meteorological Research 2008). The life cycle of each cyclone (as indicated by the dates given in Table 1) is defined to include the tropical or subtropical depression stage, but does not include remnant low or extratropical stages. The tracks and basic statistics for the season's tropical storms and hurricanes, including their depression and remnant low stages (if applicable), are given in Fig. 1 and Table 1, respectively. [Tabulations of the 6-hourly best-track positions and intensities can be found in the NHC Tropical Cyclone Reports (available online at http://www.nhc. noaa.gov/pastall.shtml). These reports contain storm information omitted here because of space limitations, including additional surface observations and a forecast and warning critique.]

Observations of eastern North Pacific tropical cyclones are almost exclusively obtained by satellite, with the primary platform being the National Oceanic and Atmospheric Administration (NOAA) Geostationary Operational Environmental Satellites (GOES). GOESEast and GOES-West provide the visible and infrared imagery that serves as input for intensity estimates using the Dvorak (1984) classification technique. Subjective Dvorak intensity estimates utilized by NHC are performed at the Tropical Analysis and Forecast Branch (TAFB) in Miami, Florida, and at the Satellite Analysis Branch (SAB) in Camp Springs, Maryland. The NHC also makes use of the Advanced Dvorak Technique (ADT; Olander and Velden 2007), an objective method that also provides satellite intensity estimates of TCs using geostationary imagery.

Occasionally, the geostationary imagery is supplemented by microwave satellite imagery from NOAA polar-orbiting satellites, Defense Meteorological Satellite Program (DMSP) satellites, and the National Aeronautics and Space Administration's (NASA) satellites that include the Tropical Rainfall Measuring Mission (TRMM) and Aqua. This microwave imagery is useful for tracking tropical cyclones and assessing their structure (Hawkins et al. 2001). The NASA Quick Scatterometer (QuikSCAT) retrieves ocean surface vector winds over a fairly wide swath while the European Space Agency's Advanced Scatterometer (ASCAT) also provides ocean surface vector winds, but over a much narrower swath. While these scatterometers have limitations (i.e., lack of horizontal resolution, rain attenuation, signal saturation, etc.) in determining a hurricane's maximum winds, they can be used to estimate the intensity of weaker systems. Careful analysis of scatterometer data can provide estimates of the location, intensity, and outer wind radii of a TC (e.g., Brennan et al. 2009). In addition, these data can be helpful in resolving whether an incipient tropical cyclone has acquired a closed surface circulation. Finally, information of the thermal structure of cyclone cores is provided by the Advanced Microwave Sounder Unit (AMSU; Demuth et al. 2006; Brueske and Velden 2003). Intensity estimates derived from these AMSU data can in some cases be superior to Dvorak classifications (Herndon and Velden 2004).

Ships and buoys occasionally provide important in situ observations of these cyclones. For systems posing a threat to land, in situ observations are also occasionally available from aircraft reconnaissance flights. The 53rd Weather Reconnaissance Squadron of the U.S. Air Force 
Reserve Command (AFRC) flew three reconnaissance missions into eastern North Pacific tropical cyclones during 2008: two in Hurricane Norbert and one in Tropical Storm Odile. Land-based radars from the Meteorological Service of Mexico were also extremely useful for monitoring TCs during 2008.

\section{a. Tropical Storm Alma, 29-30 May}

Unlike most eastern Pacific tropical cyclones, it appears that Alma formed without the assistance of a tropical wave, instead originating from a nearly stationary trough of low pressure that became established over the far eastern portion of the basin in late May. Alma's incipient low formed within the broad monsoonlike flow early on 27 May, about $225 \mathrm{n}$ mi southwest of the coast of Nicaragua. This low may have been initiated by an eastward-propagating disturbance as suggested by Hovmöller diagrams of satellite imagery (not shown). The low pressure area moved eastward, steered by the larger cyclonic gyre over the area. Shower and thunderstorm activity continued to become organized around the low on 28 May, leading to the formation of a tropical depression by 0000 UTC 29 May, centered about $85 \mathrm{n} \mathrm{mi}$ west-northwest of Cabo Blanco, Costa Rica. This genesis location is farther east than any eastern North Pacific tropical cyclone on record (excluding cyclones that originated in the Atlantic basin, crossed Central America, and reformed in the eastern Pacific).

After genesis the depression turned northward and strengthened, becoming a tropical storm $6 \mathrm{~h}$ later. Alma continued to quickly intensify, and passive microwave satellite imagery revealed an eyelike feature around 1200 UTC 29 May. The storm reached an estimated peak intensity of $55 \mathrm{kt} 6 \mathrm{~h}$ later, while centered about $45 \mathrm{n} \mathrm{mi}$ southwest of Managua, Nicaragua. Alma maintained this intensity until landfall a couple hours later, at about 1945 UTC, just southwest of Leon, Nicaragua. Alma was the first eastern North Pacific basin tropical storm or hurricane to make landfall along the Pacific coast of Central America since records began in 1949.

The tropical cyclone weakened after crossing the coast of Nicaragua, but it maintained tropical storm strength as it moved into southern Honduras just after 0000 UTC 30 May. Six hours later, Alma became a tropical depression, and by 1800 UTC the surface center dissipated over the mountains of western Honduras. A remnant low- to midlevel circulation, however, appears to have moved into the extreme western Caribbean Sea and played a role in the development of Atlantic basin Tropical Storm Arthur on 31 May.

Alma's peak intensity of $55 \mathrm{kt}$ is based on subjective Dvorak intensity estimates of $55 \mathrm{kt}$ from both TAFB and SAB. However, during the hours leading up to landfall, visible and passive microwave satellite imagery during that time showed evidence of an incipient eyelike feature. Despite the appearance of this feature, there are no quantitative data to suggest that Alma was stronger than $55 \mathrm{kt}$. The only report of sustained winds of tropical storm force in association with Alma was from an observing site in Corinto, Nicaragua. This site is located just west of where Alma made landfall, and it reported peak sustained winds of $40 \mathrm{kt}$ at 2200 UTC 29 May (Table 2). The lowest minimum pressure reported in Nicaragua was $999.8 \mathrm{mb}$ at 2100 UTC 29 May at Chinandega. Alma and its incipient low produced heavy rainfall over much of Central America. The largest amounts fell in Costa Rica and Nicaragua (Table 2). The highest storm total (2829 May) rainfall recorded in Costa Rica was $376.4 \mathrm{~mm}$ at Quepas, and the highest total reported in Nicaragua was $297.7 \mathrm{~mm}$ at Punto Sandino.

Media reports indicate that Alma was responsible for two direct deaths. One of the direct deaths occurred in Honduras when a young girl was swept away while trying to cross a flooded stream. The other death occurred offshore when a fishing vessel sank.

Alma was also responsible for seven indirect deaths. Two of the indirect deaths occurred in Nicaragua and were the result of electrocutions from downed power lines. Weather associated with Alma was also partially to blame for an aircraft accident in Tegucigalpa, Honduras, around 1600 UTC 30 May. A Transportes Aéreos del Continente Americano (TACA) Airbus A-320 carrying 133 passengers and crew skidded off the runway at the Toncontin International Airport. Three people on the plane and two others on the ground perished.

According to a report from the United Nations (UN) Office for the Coordination of Humanitarian Affairs (OCHA), the hardest hit areas in Costa Rica were the cities of Guanacaste and Punta Arenas. In these areas more than 1000 homes were damaged and 150 were destroyed from flooding. Over 100 roads and bridges in Costa Rica were damaged, which left many communities isolated for several days. According to some reports, the flooding from Alma in Costa Rica was worse than the flooding experienced from Hurricane Cesar (1996) or Mitch (1998). Monetary losses in Costa Rica are estimated at \$33 million (U.S. dollars).

The OCHA report indicated that about 200 homes were damaged in the Nicaraguan provinces of Leon and Chinandega, while in Honduras about 175 homes suffered damage. No monetary damage totals are available from Nicaragua or Honduras.

\section{b. Hurricane Boris, 27 June-4 July}

The easterly wave that spawned Boris left the west coast of Africa on 14 June. The wave moved across the 
TABLE 2. Selected surface observations for Tropical Storm Alma, 29-30 May 2008.

\begin{tabular}{|c|c|c|c|c|c|c|}
\hline \multirow[b]{2}{*}{ Location } & \multicolumn{2}{|c|}{ Min sea level pressure } & \multicolumn{3}{|c|}{ Max surface wind speed } & \multirow[b]{2}{*}{ Tot rain $(\mathrm{mm})$} \\
\hline & Date/time (UTC) & Pressure $(\mathrm{mb})$ & Date/time (UTC) & Sustained (kt) & Gust (kt) & \\
\hline \multicolumn{7}{|l|}{ Nicaragua* } \\
\hline Chinandega & $29 / 2100$ & 999.8 & $30 / 0000$ & 28 & & 267.0 \\
\hline Corinto & & & $29 / 2200$ & 40 & & 239.0 \\
\hline Masatepe & & & & & & 145.8 \\
\hline Nandaime & & & & & & 132.1 \\
\hline Monterosa & & & & & & 243.8 \\
\hline Punto Morazan & & & & & & 164.1 \\
\hline Gallo Nombre de Jesus & & & & & & 169.4 \\
\hline El Sauce & & & & & & 151.1 \\
\hline Telica & & & & & & 158.2 \\
\hline Somotillo & & & & & & 147.8 \\
\hline Los Quesos & & & & & & 149.1 \\
\hline San Isidro & & & & & & 167.9 \\
\hline Punto Sandino & & & & & & 297.7 \\
\hline Masaya & & & & & & 154.2 \\
\hline \multicolumn{7}{|l|}{ Honduras** } \\
\hline Puerto Lempira & & & & & & 113.0 \\
\hline Choluteca & & & & & & 113.3 \\
\hline \multicolumn{7}{|l|}{ Costa Rica** } \\
\hline Hacienda Mojica & & & & & & 251.2 \\
\hline La Ceiba & & & & & & 353.8 \\
\hline Santa Rosa & & & & & & 127.0 \\
\hline Jaco & & & & & & 255.5 \\
\hline Damas & & & & & & 296.9 \\
\hline P. Seco & & & & & & 337.1 \\
\hline Quepos & & & & & & 376.4 \\
\hline Golfito & & & & & & 172.7 \\
\hline Alajuela & & & & & & 202.9 \\
\hline Pavas & & & & & & 145.5 \\
\hline Upala & & & & & & 131.8 \\
\hline
\end{tabular}

* Rainfall total between 29 and 30 May.

** Rainfall total between 28 and 29 May.

Atlantic basin in about a week, showing few signs of development before it entered the eastern Pacific on 22 June. A broad surface low formed the next day south of the Gulf of Tehuantepec and convective organization increased. Thunderstorms consolidated near the center of the low late on 26 June, and the system acquired enough organization to become a tropical depression around 0600 UTC 27 June, while centered about $525 \mathrm{n}$ mi southsouthwest of Manzanillo, Mexico.

High pressure to the north of the tropical cyclone initially steered the system to the west-northwest, then more westward as the high strengthened. Moderate easterly vertical wind shear was light enough to allow the depression to become a tropical storm $6 \mathrm{~h}$ after formation, but prevented much further intensification of Boris for the next day or so. The shear lessened early on 29 June, and Boris slowly strengthened. The tropical cyclone was near hurricane strength on 30 June when a ragged eye became apparent in satellite imagery, and Boris became a hurricane the next day. The hurricane briefly weakened late on 1 July, but restrengthened on 2 July, turned to the west-northwest, and reached its peak intensity of about $70 \mathrm{kt}$. At that point, cold water and a relatively stable atmosphere induced an abrupt weakening trend. Convection associated with Boris rapidly diminished on 3 July, and the cyclone weakened to a tropical depression early on 4 July, becoming a remnant low later that day about $1270 \mathrm{n}$ mi west-southwest of the southern tip of Baja California. The low moved west to west-southwest and dissipated on 6 July just before entering the central Pacific basin.

\section{c. Tropical Storm Cristina, 27-30 June}

The genesis of Cristina can be traced to a tropical wave that crossed Central America on 21 June and moved over the eastern Pacific Ocean by 22 June. An area of showers and thunderstorms associated with the wave moved westward within the intertropical convergence zone (ITCZ) with little change in organization for several days. By 1200 UTC 26 June, several curved 
bands of deep convection became evident, and over the next day or so, the system's cloud pattern continued to become a little better organized. Data from NASA's QuikSCAT, however, showed that the surface circulation was not yet sufficiently well defined to warrant its designation as a tropical cyclone. By 1800 UTC 27 June, visible satellite imagery indicated that the low-level circulation had become more defined, and it is estimated that a tropical depression formed while centered nearly $900 \mathrm{n}$ mi southwest of the southern tip of Baja California.

The depression moved west-northwestward and strengthened into a tropical storm by 1200 UTC 28 June. Midlevel high pressure intensified to the north of Cristina, and the tropical cyclone turned toward the west. Although the vertical wind shear was not very strong over the area, Cristina was situated in a relatively stable air mass and over marginal sea surface temperatures of about $26^{\circ} \mathrm{C}$, and the cyclone did not strengthen much. The storm reached its estimated peak intensity of $45 \mathrm{kt}$ later on 28 June. Early the next day the cyclone began to weaken, apparently due to an increasingly stable air mass and greater easterly vertical wind shear. Over the next day or so, Cristina produced some bursts of deep convection but became mostly devoid of banding features while its maximum winds gradually decreased. By 1200 UTC 30 June, the system had lost most of its deep convection, and it is estimated that the cyclone weakened to a tropical depression. A little later that day, the westward-moving depression degenerated into a remnant low pressure area, and the low eventually dissipated on 3 July about $1700 \mathrm{n}$ mi west-southwest of the southern tip of Baja California.

\section{d. Tropical Storm Douglas, 1-4 July}

Douglas originated from a tropical wave that moved off the west coast of Africa on 19 June accompanied by an organized area of cloudiness and thunderstorms. The wave continued quickly westward across the Atlantic and the southern Caribbean Sea but its associated shower activity diminished. After the wave crossed Central America on 27 June, it developed deep convection and a broad low-level circulation. The disturbance continued westward and on 28 June it was located a few hundred miles south of the Gulf of Tehuantepec. A well-defined circulation center eventually developed and it is estimated that the system became a tropical depression at 1800 UTC 1 July, about $245 \mathrm{n}$ mi southwest of Manzanillo.

Strong northeasterly wind shear kept the center on the northern edge of the convection and prevented significant strengthening. Nevertheless, the depression strengthened slightly and became a tropical storm around 1200 UTC 2 July. Around that time, outer rainbands associated with Douglas produced tropical storm-force wind gusts in Manzanillo, and locally heavy rains were reported in southwestern Mexico. Douglas moved toward the northwest and began to weaken gradually due to both increasing shear and cooler waters. The cyclone became a remnant low at 0600 UTC 4 July and was turned westward by the low-level flow, dissipating a couple of days later.

\section{e. Hurricane Elida, 11-19 July}

Elida formed from a tropical wave that moved off the coast of Central America on 8 July, although there was little prior evidence of the wave in the Atlantic basin. The wave developed a low pressure center by 1200 UTC 10 July, but convection associated with the system was quite limited. Early on 11 July the organization and amount of the convection increased, and it is estimated that a tropical depression formed around 1800 UTC 11 July, when the system was centered about $315 \mathrm{n} \mathrm{mi}$ south-southeast of Puerto Angel, Mexico.

A low- to midlevel ridge extended westward from the Gulf of Mexico across western Mexico, and the depression initially moved west-northwestward to the south of this feature. Easterly vertical wind shear that had been present during the initial development of the cyclone lessened, and the depression became a tropical storm near 0600 UTC 12 July, about $200 \mathrm{n}$ mi south of Puerto Angel. Elida gradually strengthened as it continued west-northwestward on 12 and 13 July, turning westward the following day as a mid- to upper-level trough west of the Baja California peninsula weakened. During this period, the center of Elida remained about 175-200 n mi off the Pacific coast of Mexico, far enough offshore for the cyclone to have little or no impact on the weather along the coastline. Elida attained hurricane strength near 1200 UTC 14 July while centered about $300 \mathrm{n} \mathrm{mi}$ southwest of Manzanillo, and reached an estimated intensity of $75 \mathrm{kt}$ later that day.

Over the next two days Elida moved westward over open waters to the south of a deep-layer subtropical ridge. An increase in easterly shear could have caused a slight weakening of the hurricane on 15 July. However, on 16 July the cloud pattern became more symmetric and microwave imagery showed an eye feature developing. Even though Elida was very near the $26^{\circ} \mathrm{C}$ sea surface temperature isotherm, it strengthened to a peak intensity of $90 \mathrm{kt}$ near 1800 UTC 16 July (Fig. 3), when the center was located about $550 \mathrm{n}$ mi southwest of Cabo San Lucas, Mexico. Early on 17 July Elida crossed the $26^{\circ} \mathrm{C}$ isotherm, and the eye, which had become apparent in geostationary imagery, disappeared. Easterly shear and cooler waters combined to induce a weakening trend, with the cyclone falling below hurricane intensity early on 18 July and weakening to a depression 


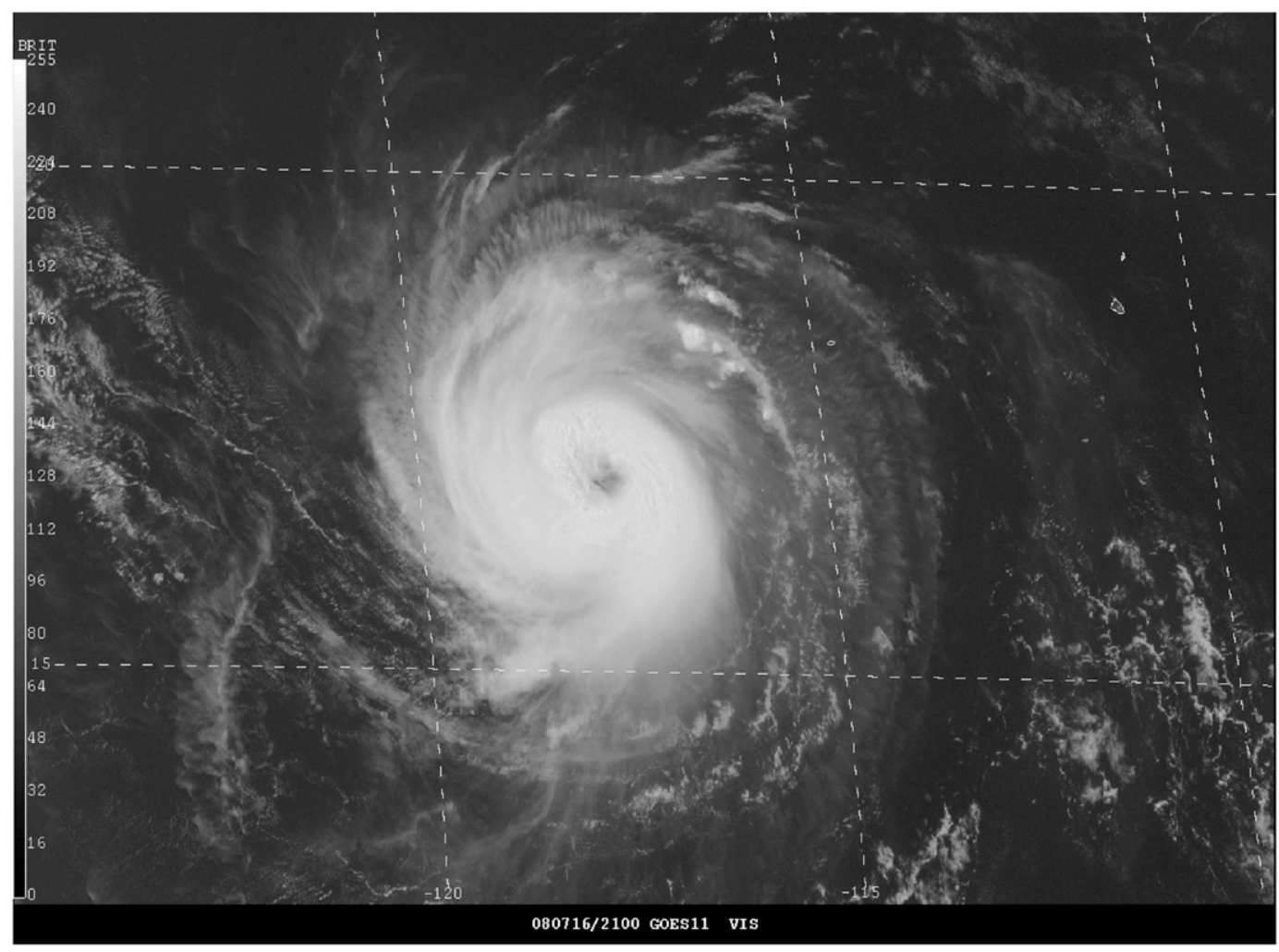

FIG. 3. GOES-11 visible image of Hurricane Elida at 2100 UTC $16 \mathrm{Jul} 2008$, near its peak intensity of 90 kt.

a day later. Despite maintaining a well-defined circulation, Elida was unable to generate deep convection after about 0600 UTC 19 July, thus marking the degeneration of the system to a remnant low about $1300 \mathrm{n}$ mi east of the Hawaiian Islands. The low moved just south of due west until dissipating into an open trough about $600 \mathrm{n} \mathrm{mi}$ east-southeast of the Hawaiian Islands.

\section{f. Hurricane Fausto, 16-22 July}

A tropical wave moved westward from the coast of Africa on 4 July, reaching the eastern Pacific on 12 July. The associated shower activity first showed signs of organization on 13 July, though subsequent development was slow while the system moved erratically westward on 14-15 July. Development began in earnest late on $15 \mathrm{July}$, and it is estimated that a tropical depression formed near 0600 UTC 16 July about $480 \mathrm{n}$ mi southeast of Acapulco, Mexico. The depression became a tropical storm $6 \mathrm{~h}$ later.

The cyclone moved west-northwestward and then westward at about $20 \mathrm{kt}$ through 16 July, then began a west-northwestward motion at a slower forward speed to the south of a midlevel ridge on 17 July. Fausto initially had a relatively broad convective core, with the primary convection located in bands $60-90 \mathrm{n} \mathrm{mi}$ from the center on 17 July. As the storm consolidated, it slowly strengthened and became a hurricane on 18 July about $370 \mathrm{n} \mathrm{mi} \mathrm{south-southwest} \mathrm{of} \mathrm{Manzanillo.} \mathrm{Fausto}$ turned to the northwest toward a weakness in the ridge on 19 July. The hurricane reached an estimated peak intensity of $80 \mathrm{kt}$ on 20 July as it passed between Socorro and Clarion Islands.

Fausto weakened to a tropical storm on 21 July as it moved west-northwestward over decreasing sea surface temperatures. It weakened to a tropical depression the next day and then became a nonconvective remnant low on 23 July about $665 \mathrm{n}$ mi west of Cabo San Lucas before dissipating on 24 July.

There were two observations of tropical storm-force or greater winds from Fausto. The Mexican automated station on Clarion Island reported sustained winds of $56 \mathrm{kt}$ with a gust of $82 \mathrm{kt}$ at 1814 UTC 20 July. These winds occurred several hours before the closest approach of the center, and later observations were unavailable. The automated station on Socorro Island reported sustained winds of $69 \mathrm{kt}$ at 1013 UTC 20 July, with a gust of $95 \mathrm{kt}$ at 1213 UTC that day. However, this report appears somewhat suspect, as the closest approach of Fausto's center to Socorro was about $100 \mathrm{n} \mathrm{mi}$. 


\section{g. Hurricane Genevieve, 21-27 July}

Genevieve formed from a tropical wave that moved across the coast of Africa on 6 July. The wave moved south of a strong subtropical ridge across the North Atlantic, passing into the Caribbean Sea on 14 July, and spawned a surface low pressure system on 16 July over the western Caribbean Sea. The system was showing signs of organization on 17 July before it moved onshore into Nicaragua. The wave then crossed Central America, bringing heavy rains to much of the region. The low center moved off the coast of El Salvador into the eastern Pacific on 19 July.

The organization of the deep convection was limited over the next two days while the system moved westward through a region of moderate easterly vertical wind shear on the southern edge of a strong upper-level high pressure system centered over southwestern Mexico. The wind shear began to relax on 21 July, which allowed the deep convection associated with the low to become better organized. It is estimated that a tropical depression formed around 1200 UTC 21 July approximately $220 \mathrm{n} \mathrm{mi}$ south-southwest of Acapulco. Data from ASCAT and Dvorak intensity estimates suggest that the depression reached tropical storm strength by 1800 UTC that day.

Although the vertical wind shear affecting Genevieve continued to decrease, on 22 July the cyclone began to move over anomalously low sea surface temperatures in the wake of Hurricane Fausto, which had passed through the same region about 5 days earlier (17-19 July). The passage of Genevieve over this cold pool is suspected to have caused the temporary decrease in intensity from 1200 UTC 23 July to 0600 UTC 24 July.

After traversing the cooler waters, Genevieve reached hurricane strength near 1200 UTC 25 July, centered about $510 \mathrm{n}$ mi southwest of Cabo San Lucas, Mexico, and continued moving generally westward. Genevieve's time as a hurricane was brief, and it weakened to tropical storm status by 0600 UTC 26 July as it encountered increasing southeasterly wind shear around the western periphery of the mid- to upper-level ridge over the eastern North Pacific. Genevieve passed over cooler waters and into a region of increasing northerly wind shear, further weakening to a tropical depression around 0600 UTC 27 July. The depression degenerated into a remnant low approximately $6 \mathrm{~h}$ later, maintaining a closed circulation for 4 more days until dissipating near the time it entered the central Pacific basin.

\section{h. Hurricane Hernan, 6-12 August}

Hernan was the first major hurricane of the season, taking a typical track offshore of Mexico. The hurricane developed from a tropical wave that departed the west coast of Africa on 24 July. The wave produced only limited shower activity while traversing the Atlantic and Caribbean waters during the next week or so. After entering the eastern Pacific basin on 2 August, the wave moved into an existing area of broad cyclonic flow located a few hundred miles south of the coast of Mexico. The interaction between these two features produced an area of low pressure centered about $525 \mathrm{n}$ mi south of Manzanillo on 5 August. Convection increased in association with the low early the next day, and by 1200 UTC 6 August, when the system was centered about $675 \mathrm{n} \mathrm{mi}$ south-southwest of the southern tip of Baja California, the low had enough organization to be considered a tropical depression.

The organization of the depression continued to increase, and Dvorak satellite intensity estimates indicate that it reached tropical storm strength by 0000 UTC 7 August. Despite moderate east-northeasterly wind shear, Hernan gradually strengthened during the next day or so while moving in a west to west-northwestward direction to the south of a midtropospheric ridge. Around 1200 UTC 7 August, an eyelike feature was detected in microwave imagery, although it was displaced to the southwest of the low-level center due to the shear. Early on 8 August, as the shear began to relax, the low- and midlevel centers became more vertically aligned. Shortly thereafter, a ragged eye appeared in geostationary satellite imagery and it is estimated that Hernan attained hurricane strength while located about 775 miles southwest of the southern tip of Baja California. During the next 24 h, Hernan rapidly intensified, developed a classic well-defined eye (Fig. 4) and reached an estimated peak intensity of $105 \mathrm{kt}$ at 1200 UTC 9 August. A series of microwave images between 1553 UTC 9 August and 1508 UTC 10 August (Fig. 5) show that Hernan then underwent an eyewall replacement. During this time, the hurricane also began traversing cooler waters, and these factors contributed to a gradual weakening of the cyclone. Additional weakening over even cooler waters on 11 August resulted in Hernan becoming a tropical storm around 0000 UTC 12 August. Over the next 24 h, the cyclone turned west-southwestward, and the remaining convection gradually dissipated. Hernan degenerated into a remnant low around 0000 UTC 13 August and eventually dissipated about $400 \mathrm{n}$ mi southeast of the island of Hawaii on 16 August.

\section{i. Tropical Storm Iselle, 13-16 August}

The easterly wave that generated Iselle left the African coast on 30 July. The wave moved quickly across the Atlantic basin in about a week with little organized convection, eventually entering the eastern Pacific Ocean on 7 August. Showers and thunderstorms increased markedly 


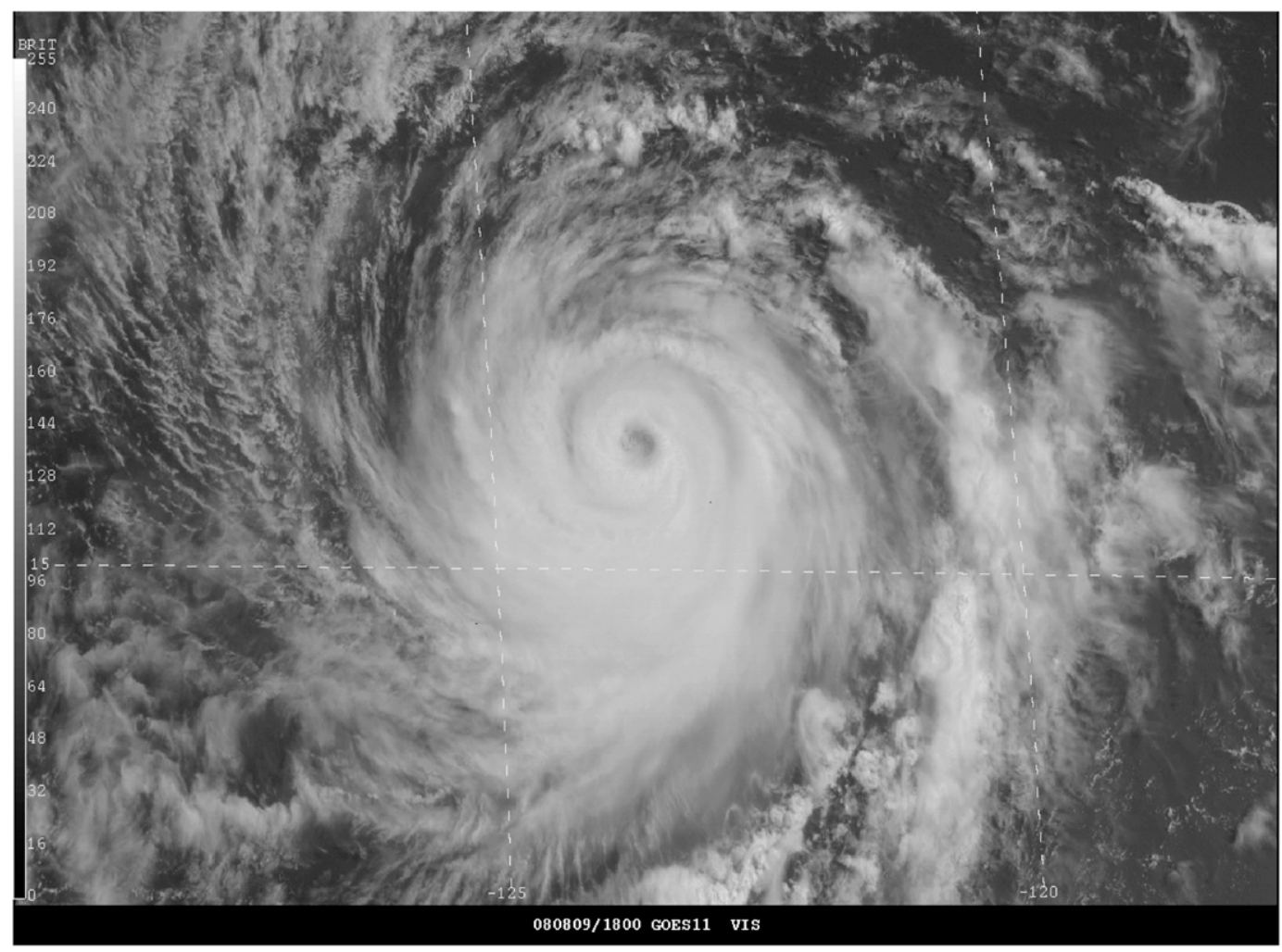

FIG. 4. GOES-11 visible image of Hurricane Hernan at 1800 UTC 9 Aug 2008, at its peak intensity of 105 kt.

near the wave while it was over Central America, and a surface low formed early on 8 August. However, this low weakened the next day, with only sporadic shower and thunderstorm activity occurring over the next couple of days. Late on 12 August, thunderstorms increased near the center, and around 1200 UTC 13 August, the low became a tropical depression, centered about $180 \mathrm{n} \mathrm{mi}$ south-southwest of Manzanillo. Six hours later, the depression intensified to a tropical storm.

High pressure to the north of the tropical cyclone initially helped steered the system toward the westnorthwest at about $10 \mathrm{kt}$. Moderate easterly wind shear allowed only a slight intensification, and Iselle achieved a peak intensity of $45 \mathrm{kt}$ on the morning of 14 August. Thereafter, a combination of increasing wind shear, somewhat cooler waters, and entrainment of stable air caused a gradual weakening of the tropical storm. After it reached its peak intensity, Iselle took an erratic track generally toward the northwest, as high pressure north of the cyclone weakened. Early on 16 August, Iselle weakened to a tropical depression and became a remnant low about $24 \mathrm{~h}$ later, about $1270 \mathrm{n}$ mi west-southwest of the southern tip of Baja California. The low moved to the west for the next few days, then to the southwest, redeveloping a small amount of convection on 22 August before dissipating the next day.

\section{j. Tropical Storm Julio, 23-26 August}

The tropical wave that moved off the west coast of Africa on 6 August and spawned Atlantic Tropical Storm Fay on 15 August near Puerto Rico, also appears to have produced Julio. The wave crossed southern Central America and moved over the eastern Pacific Ocean on 17 August. There was not much organized deep convection associated with the wave as it proceeded westward to the south of Central America and Mexico over the next several days. By 21 August, there was an increase in showers and thunderstorms associated with the system while it was located a couple hundred miles to the south of Acapulco. A broad surface low pressure system soon formed in this region, but development was hindered by strong easterly vertical wind shear. By 1200 UTC 23 August, however, when the system was centered about $315 \mathrm{n}$ mi south-southeast of Cabo San Lucas, deep convection became persistent enough near the center of the low to warrant its designation as a tropical depression.

About $6 \mathrm{~h}$ after formation, the depression strengthened slightly and became a tropical storm. Julio moved northnorthwestward along the periphery of a midtropospheric high pressure area over west-central Mexico. Although east-northeasterly wind shear continued to inhibit significant intensification, the storm strengthened a little 
a) 1553 UTC 9 August

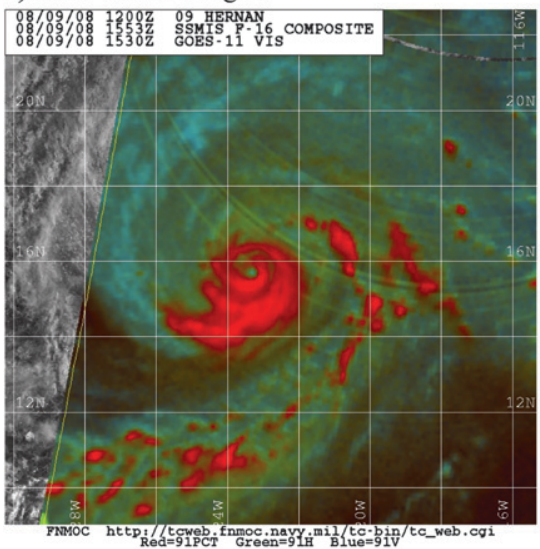

d) 1019 UTC 10 August

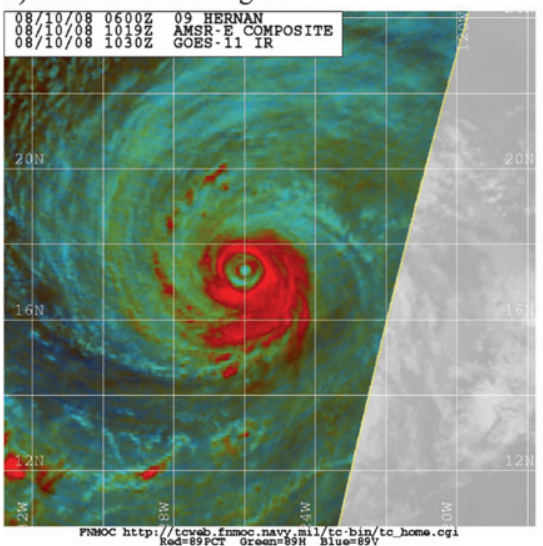

b) 2207 UTC 9 August

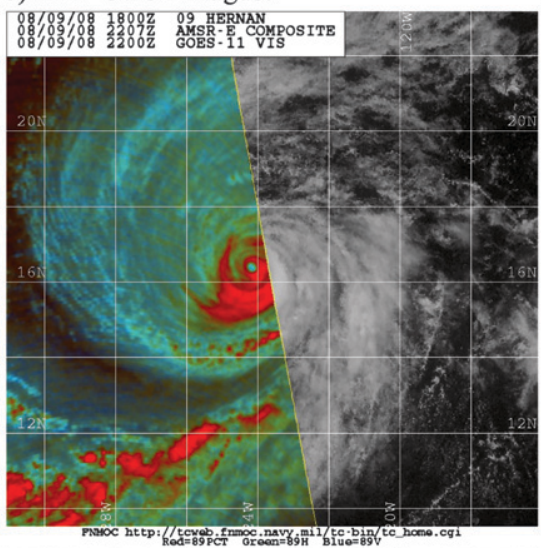

e) 1258 UTC 10 August

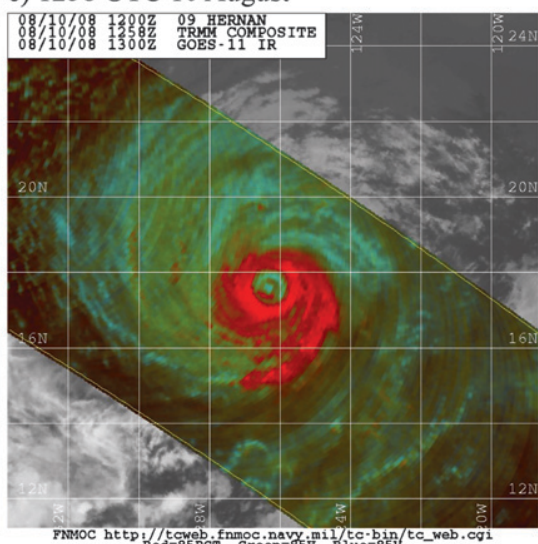

c) 0242 UTC 10 August

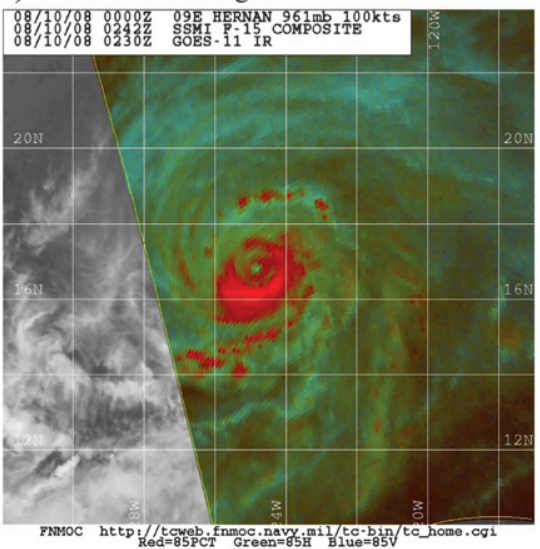

f) 1508 UTC 10 August

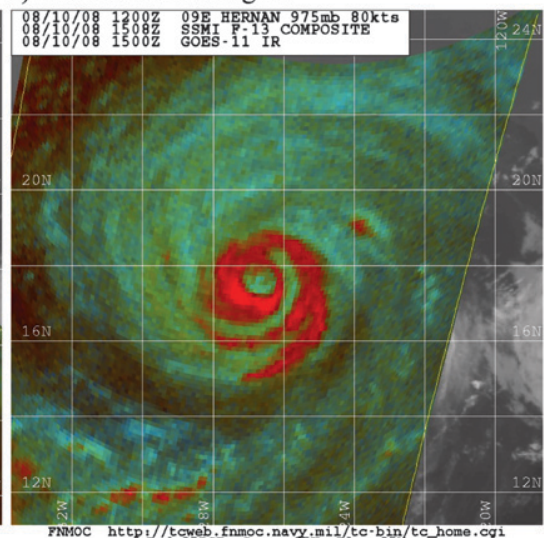

FIG. 5. Series of composite 85-91-GHz passive microwave images showing Hurricane Hernan completing an eyewall replacement between 1553 UTC 9 Aug and 1508 UTC 10 Aug 2008. Note the (d) well-defined double-eyewall structure and (f) the dissipation of the inner eyewall. [Images courtesy of the Fleet Numerical Meteorology and Oceanography Center (FNMOC).]

more, achieving a maximum intensity of $45 \mathrm{kt}$ around 1200-1800 UTC 24 August, during which time the center passed near and just west of Cabo San Lucas. Julio then made landfall in southern Baja California, about $35 \mathrm{n} \mathrm{mi}$ west-southwest of La Paz around 0000 UTC 25 August, with an estimated intensity of $40 \mathrm{kt}$. The system continued to move north-northwestward across the Baja peninsula that day while slowly weakening. Julio turned northward, and its center reached the Gulf of California in the vicinity of Santa Rosalia just before 0000 UTC 26 August, by which time the cyclone had weakened to a tropical depression. Julio slowed and turned eastward over the central Gulf of California while gradually weakening, and degenerated into a remnant low by 1800 UTC 26 August. The low drifted eastward, and it dissipated near Tastiota on the coast of mainland Mexico around 1200 UTC 27 August.

A pair of ships reported tropical-storm-force winds associated with Julio. At 2000 UTC 23 August, the NYK Galaxy measured 40-kt winds and a pressure of
$1004.0 \mathrm{mb}$. Four hours later, the Hoechst Express reported 35-kt winds and a pressure of $1004.5 \mathrm{mb}$. The only report of a land station with tropical storm-force winds was at Cabo San Lucas. This automatic station, operated by the Meteorological Service of Mexico, reported a 10-min average wind of $38 \mathrm{kt}$ with a gust to $51 \mathrm{kt}$ around 1600 UTC 24 August. The wind sensor is at an elevation of about $224 \mathrm{~m}$ above sea level. Twentyfour hour rainfall totals of 166.1 and $132.1 \mathrm{~mm}$ were reported in southern Baja California at Loreto on 24 August and at Mulege on 25 August, respectively.

Julio caused one death, a drowning near Mulege. There was flooding elsewhere over the peninsula, but damage estimates were not available.

\section{k. Tropical Storm Karina, 2-3 September}

The development of Karina appears to be associated with the same tropical wave that spawned Gustav in the Caribbean Sea. While Gustav was over Hispaniola, the southern portion of the wave continued westward across 
the Caribbean Sea and moved over Central America on 28 August, accompanied by limited shower activity. The convection gradually increased as the wave continued westward across the eastern North Pacific. The wave finally triggered the development of a low pressure area near the coast of Mexico to the south of Manzanillo on 30 August.

Strong easterly wind shear kept most of the thunderstorm activity separated from the center of the low as the system continued westward. However, deep convection eventually became sufficiently organized about the low center to mark the formation of a tropical depression at 0600 UTC 2 September, when the system was located about $340 \mathrm{n}$ mi south of the southern tip of Baja California. There was a minor relaxation of the wind shear, and the depression became a tropical storm at 1200 UTC 2 September, as indicated by a QuikSCAT pass a couple hours later. Thereafter, the shear increased again and the convection became separated from the center. Steady weakening began, and by 1800 UTC 3 September, Karina degenerated to a remnant low, which quickly dissipated.

\section{l. Tropical Storm Lowell, 6-11 September}

Lowell's formation resulted from a complex interaction of a surface trough off the coast of Mexico and a westward-moving tropical wave. The tropical wave initially moved off the coast of Africa on 19 August, eventually causing the development of Hurricane Hanna in the Atlantic basin northeast of the Leeward Islands. The southern portion of the wave continued to move westward across the Caribbean Sea and crossed Central America on 27 and 28 August. By that time, strong southwesterly low-level flow and a surface trough had developed off the coast of southern Mexico. The tropical wave moved very slowly westward through the large area of cyclonic flow associated with the trough and induced a gradual increase in deep convection. As the wave reached the western edge of the trough, a smaller embedded circulation developed within the wave and eventually detached from the large cyclonic flow area. It is estimated that the smaller circulation became a tropical depression at 1200 UTC 6 September when it was centered about $255 \mathrm{n}$ mi south of Manzanillo. A prominent convective band formed that day, and the depression strengthened into a tropical storm $12 \mathrm{~h}$ later.

A deep-layer anticyclone over Mexico helped steer Lowell northwestward during the next couple of days. Strong upper-level winds on the south side of the anticyclone produced about $20 \mathrm{kt}$ of northeasterly-to-easterly shear over the cyclone for several days, and the low-level center of Lowell remained exposed to the northeast of the deep convection. Lowell reached and then maintained a peak intensity of $45 \mathrm{kt}$ from 1200 UTC 7 September through 0600 UTC 8 September as it moved very close to Socorro Island.

Vertical wind shear decreased across Lowell by 9 September as the cyclone reached the western periphery of the subtropical ridge. However, the tropical storm had already begun to ingest drier, more stable air originating from west of Baja California. The circulation began to slowly spin down, and QuikSCAT data indicate that Lowell weakened to a tropical depression at 0600 UTC 10 September as it was moving northnortheastward about $180 \mathrm{n}$ mi west-southwest of the southern tip of Baja California. Thunderstorm activity and the midlevel center of Lowell became sheared northeastward across southern Baja California and into northwestern mainland Mexico ahead of an upper-level trough. The depression then turned to the east-northeast and made landfall near Cabo San Lucas at 0900 UTC 11 September as a 30-kt depression. By 1800 UTC, satellite imagery and surface observations indicate that the circulation of Lowell opened up into an elongated surface trough that extended across the southern Gulf of California.

There were no surface land station or ship reports of winds of tropical storm-force associated with Lowell. However, two unofficial stations in Cabo San Lucas reported minimum pressures of $998.5 \mathrm{mb}$ (IBAJACAL9) and $1000.6 \mathrm{mb}$ (IBAJACAL12) at 0915 and 0925 UTC 11 September, respectively, as the center of Lowell moved over the area.

Heavy rainfall from the remnants of Lowell caused streams and canals to overflow in the Mexican states of Sonora and Sinaloa, leaving more than 26500 people homeless. The cities of Navojoa, Benito Juarez, Huatabampo, and Etchojoa were most affected. The government of Sonora has estimated a damage total in that state of about $\$ 15.5$ million (U.S. dollars).

The remnants of Lowell later merged with a frontal boundary over the central United States and caused heavy rainfall and flooding 1-2 days before the remnants of Atlantic basin Hurricane Ike passed through the region. The swath of heaviest rain fell from Kansas to northern Illinois and Indiana. Wichita, Kansas, measured a daily record $261.9 \mathrm{~mm}$ of rain on 12 September and broke the 24-h rainfall record of $202.9 \mathrm{~mm}$ that had been held since 1911. Chicago, Illinois, reported $168.7 \mathrm{~mm}$ at O'Hare International Airport, the highest 1-day total since records began in 1871. Numerous people were rescued from stranded vehicles as rainfall flooded city streets.

\section{m. Hurricane Marie, 1-6 October}

Marie originated from a tropical wave that emerged from the west coast of Africa on 12 September. This was 
the same wave that spawned the low that eventually became Hurricane Kyle in the Atlantic basin. The southern portion of the wave reached Central America on 22 September. Two days later, when the wave emerged over the eastern North Pacific, a few weak bands of convection developed. However, this system showed no signs of having a closed surface circulation until 28 September, when the system was located about $300 \mathrm{n}$ mi south of Manzanillo. The low pressure system moved west-northwestward for the next week or so and gradually acquired enough convective organization to be classified as a tropical depression at 0600 UTC 1 October when the cyclone was centered about $510 \mathrm{n}$ mi southwest of the southern tip of Baja California, Mexico. Six hours later, the depression intensified into a tropical storm.

Marie reached and maintained an estimated intensity of $45 \mathrm{kt}$ over the ensuing $24 \mathrm{~h}$. A second intensification phase occurred between 0000 UTC 3 October and 0000 UTC 4 October, during which time Marie reached hurricane status about $755 \mathrm{n}$ mi west-southwest of the southern tip of Baja California. The hurricane achieved a peak intensity of $70 \mathrm{kt}$ early on 4 October, but by 1200 UTC 4 October, a steady weakening trend was evident. The system turned westward and moved slowly into a more stable atmospheric environment with sea surface temperatures below $26^{\circ} \mathrm{C}$. Marie weakened to a tropical storm late on 4 October, became a depression around 1200 UTC 6 October, and degenerated into a nonconvective low pressure system $12 \mathrm{~h}$ later when the cyclone was located about $860 \mathrm{n}$ mi west-southwest of Cabo San Lucas. Marie's persistent remnant circulation moved erratically to the southwest and west-southwest and on 19 October, the system was finally absorbed into the ITCZ about $1050 \mathrm{n}$ mi east-southeast of the Hawaiian Islands.

There was only one ship that reported tropical stormforce winds associated with Marie. At 0600 UTC 5 October, the ship Jo Spruce, located about $70 \mathrm{n}$ mi north of the center of Marie, reported easterly winds of $35 \mathrm{kt}$ and a pressure of $1009.0 \mathrm{mb}$.

\section{n. Hurricane Norbert, 4-12 October}

Norbert, the strongest hurricane of the season, originated out of a large and slow-moving area of low pressure that developed south of the Gulf of Tehuantepec on 28 September. The initial surface low appears to have been associated with a tropical wave that crossed Central America on 26-27 September, with a second tropical wave reaching the area on 2 October. The following day, convection associated with the low became more concentrated and persistent, and it is estimated that a tropical depression formed around 0000 UTC 4 October, centered about $210 \mathrm{n}$ mi south-southeast of Acapulco.
Initially nearly stationary, the depression soon began to move slowly westward to the south of a building midlevel high pressure ridge. Easterly vertical wind shear limited development, and the depression took $24 \mathrm{~h}$ to reach tropical storm strength, which occurred around 0000 UTC 5 October when the system was centered about $170 \mathrm{n}$ mi south-southwest of Acapulco. The easterly shear abated somewhat over the next couple of days, but Norbert continued to intensify only slowly, becoming a hurricane around 0600 UTC 7 October while centered about $270 \mathrm{n}$ mi south-southwest of Manzanillo.

Now moving west-northwestward around the periphery of the subtropical ridge, the hurricane began a period of rapid strengthening on 7 October. By midday, microwave imagery revealed a partially closed banding eyewall, and the cirrus outflow became better defined. Norbert intensified by $40 \mathrm{kt}$ over the ensuing $24 \mathrm{~h}$ and reached its peak intensity of $115 \mathrm{kt}$ near 1800 UTC 8 October (Fig. 6). At this time the center was located about 390 n mi south of Cabo San Lucas, Mexico.

Norbert was still over warm waters and embedded within light vertical shear, however structural changes within the hurricane appear to have prevented additional strengthening. By 0900 UTC 9 October, additional microwave passes indicated that the eyewall had eroded significantly, with more-circular (albeit not quite concentric) outer banding. Concurrent infrared imagery indicated that the core deep convection had weakened, suggesting the onset of an eyewall replacement cycle. By the time a reconnaissance aircraft arrived at the center of Norbert near 1800 UTC, the hurricane had weakened to category 1 strength, with maximum winds of near $70 \mathrm{kt}$.

On 10 October Norbert turned northward and its forward motion slowed when it reached the westward extent of the subtropical ridge. Wind shear was still light, and Norbert began to restrengthen as it completed the eyewall replacement cycle. Norbert turned to the northnortheast ahead of a mid to upper-level trough dropping southward over the southwestern United States, and the hurricane's maximum winds reached $100 \mathrm{kt}$ near 0600 UTC 11 October. At this point the center of Norbert was about $160 \mathrm{n}$ mi west of Cabo San Lucas. Turning northeastward and accelerating, Norbert weakened slightly as it approached Baja California, making landfall on the peninsula near Puerto Chale in the state of Baja California Sur, just southeast of Bahia Magdalena, around 1630 UTC 11 October. At the time of landfall, Norbert's maximum winds are estimated to have been near $90 \mathrm{kt}$ (category 2 strength), making Norbert the strongest hurricane on record to strike the western Baja California coast.

Norbert crossed the peninsula, and its center emerged into the Gulf of California around 2100 UTC. Strong 


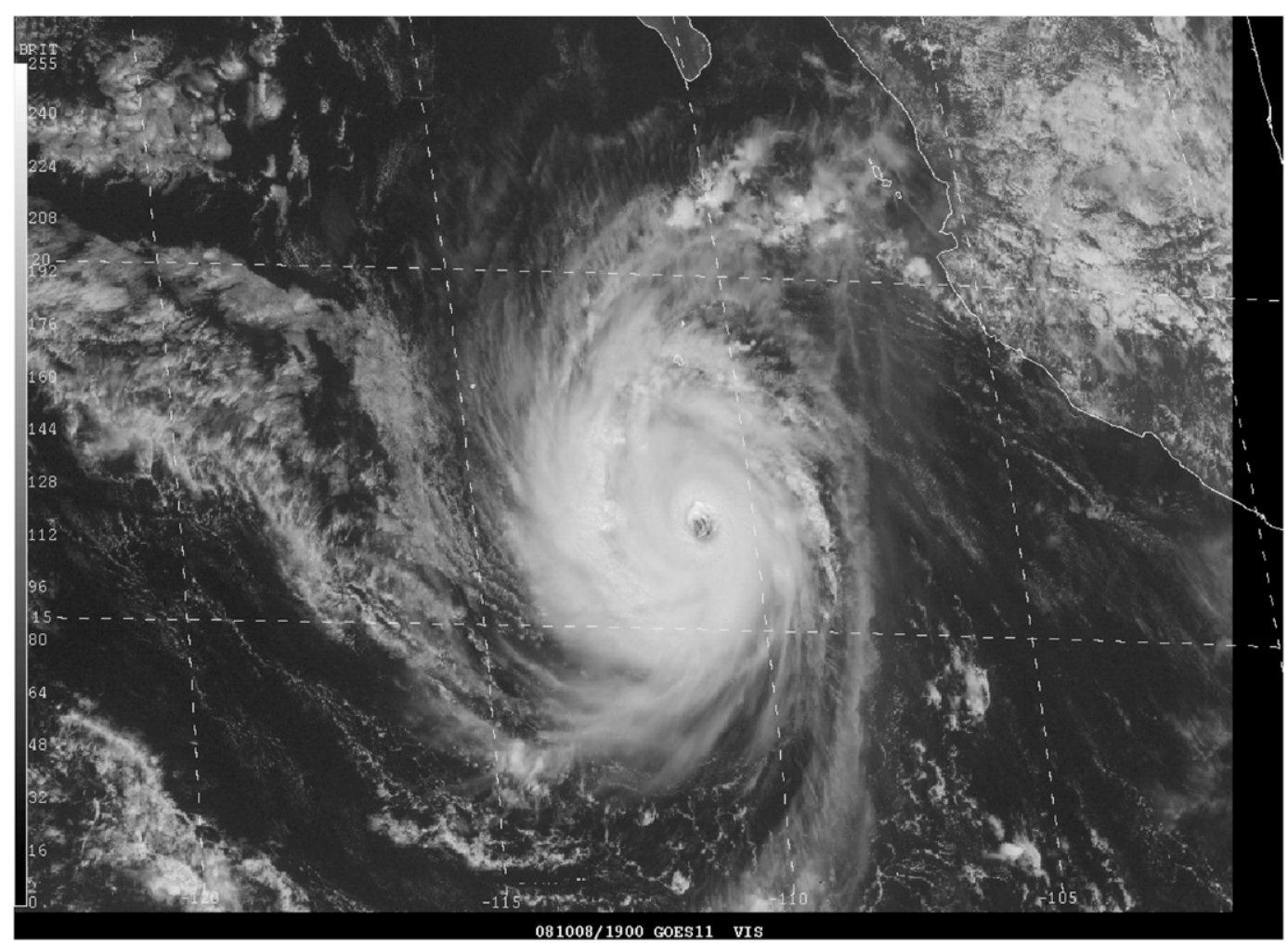

FIG. 6. GOES-11 visible image of Hurricane Norbert at 1900 UTC 8 Oct 2008, near the time of its peak intensity of $115 \mathrm{kt}$.

vertical wind shear and the cyclone's passage over land caused the hurricane to continue to weaken. Norbert reached the coast of mainland Mexico as a category 1 hurricane with estimated peak winds of $75 \mathrm{kt}$, about $20 \mathrm{n} \mathrm{mi}$ east-southeast of Huatabampo in the state of Sonora near 0400 UTC 12 October. Norbert then continued moving northeastward and rapidly weakened, becoming a tropical storm within a few hours of making its final landfall and becoming a tropical depression by 1200 UTC that day. By 1800 UTC, the circulation had dissipated over the mountains of northeastern Mexico.

There were no reliable ship reports of winds of tropical storm force associated with Norbert, and land-based observations from the affected areas were extremely limited. Sustained winds of $50 \mathrm{kt}$, with gusts to $60 \mathrm{kt}$, were reported at the airport at Los Mochis (MMLM) around 0200 UTC 12 October. The maximum 24-h reported rainfall was $121.3 \mathrm{~mm}$ at Ciudad Constitucion on the Baja California peninsula.

Information from meteorological and civil defense officials in Mexico indicated there were five deaths directly associated with Norbert in Alamos, Sonora. These deaths, two women and three men, were associated with river floodwaters.
Media reports indicated that nearly half of the homes on the islands of Margarita and Magdalena, near the first landfall site, were totally or partially damaged, mostly from roof damage. Electricity was reportedly cut off to roughly 20000 homes in Baja California. Rushing, kneedeep water was reported in the town of Ciudad Constitucion. Unspecified surge flooding was reported in the fishing town of Puerto San Carlos.

\section{o. Tropical Storm Odile, 8-12 October}

Odile had a complex origin involving a number of weather systems. A tropical wave moved westward from the coast of Africa on 23 September and merged with another area of vorticity over the tropical Atlantic on 26 September, with the combined system continuing westward. The wave reached the western Caribbean Sea on 4 October, where it merged with the southern end of a preexisting frontal system. The northern end of this combined system moved west-northwestward across the Yucatan Peninsula, where it contributed to the formation of Tropical Storm Marco in the Bay of Campeche. Meanwhile, the southern end of the system moved westward into the eastern Pacific and almost immediately showed signs of organization. However, the development was impeded by easterly vertical wind shear 
while the system stalled south of El Salvador on 5 October. There was little motion or change in organization during the next couple of days. Early on 8 October, another tropical wave moved into the eastern Pacific and approached the disturbance. Development resumed at that time, and it is estimated that a tropical depression formed at 1200 UTC that day about $105 \mathrm{n}$ mi southsouthwest of San Salvador, El Salvador.

A large mid- to upper-level ridge over Mexico helped steer the depression west-northwestward as it formed, with the center passing south of the Gulf of Tehuantepec while the system became a tropical storm on 9 October. A northwestward turn on 10 October was followed by a west-northwestward motion on 11 October, a track that kept the center moving parallel to the coast of Mexico about $40 \mathrm{n} \mathrm{mi} \mathrm{offshore.} \mathrm{Odile} \mathrm{reached} \mathrm{an} \mathrm{estimated}$ peak intensity of $50 \mathrm{kt}$ on both 10 and 11 October. Subsequently, increasing southeasterly vertical wind shear caused rapid weakening. The cyclone became a tropical depression early on 12 October and decayed into a remnant low early on 13 October about $45 \mathrm{n} \mathrm{mi}$ south of Manzanillo. The low moved slowly southsouthwestward before dissipating later that day.

Two ships reported winds of tropical storm force in Odile. The Saga Pioneer reported sustained 52-kt winds and a pressure of $1002.0 \mathrm{mb}$ at 1500 UTC 10 October. The Westerdam reported 35-kt winds at 0400 UTC 9 September. There were no reports of tropical stormforce winds from coastal stations in Mexico.

\section{p. Tropical Storm Polo, 2-5 November}

Polo was a late-season, low-latitude storm that developed from a tropical wave that moved off the west coast of Africa on 15 October. The wave moved steadily westward across the Atlantic Ocean and Caribbean Sea with limited deep convection and then crossed Central America between 27 and 29 October. Once the wave moved into the eastern Pacific, a small area of deep convection developed near the wave axis within the ITCZ. A small area of low pressure then developed along the wave axis and eventually became a tropical depression at 1200 UTC 2 November, centered approximately $680 \mathrm{n}$ mi south-southwest of Manzanillo. The depression continued to move westward and strengthened into a tropical storm $12 \mathrm{~h}$ later.

Polo appeared to partially detach from the ITCZ but never fully separated. Yet early on 3 November, microwave satellite imagery indicated that Polo had developed a small, well-defined circulation and a ring of thunderstorm activity surrounding a tiny eyelike feature. The thunderstorm activity then nearly vanished between 1200 UTC 3 November and 0000 UTC 4 November before a larger area of deep convection rede- veloped on 4 November. The deep convection became disorganized because of a west-northwesterly shear, and Polo weakened to a tropical depression at 0000 UTC 5 November. Soon afterward, the low-level center degenerated into a surface trough, which continued to propagate westward through the ITCZ.

Polo was a small tropical cyclone. Its estimated peak intensity of $40 \mathrm{kt}$ between 0600 UTC and 1200 UTC 3 November is based on a 1338 UTC 3 November QuikSCAT pass, and on objective satellite intensity technique estimates of $40 \mathrm{kt}$. This period coincided with the time when Polo developed the tight ring of deep convection and small eye feature. However, it is important to note that the intensity of small tropical cyclones is often difficult to estimate with the Dvorak technique, and it is possible that Polo could have been more intense than indicated by satellite techniques.

Polo became a tropical storm while centered at a latitude of $8.7^{\circ} \mathrm{N}$. Historical records indicate that only four other tropical cyclones in the eastern North Pacific developed into tropical storms at a lower latitude: Tropical Storm Jimena (1979), Hurricane Agatha (1980), Hurricane Adolph (1983), and Tropical Storm Velma (1983).

\section{q. Unnamed depressions}

There were two unnamed depressions during 2008. Tropical Depression Five-E was a short-lived tropical cyclone that originated from a tropical wave that crossed Central America on 2 July. The incipient system gradually gained organization over the extreme eastern Pacific during the next couple of days, and the depression formed on 5 July about $150 \mathrm{n}$ mi south-southeast of Acapulco. The cyclone initially moved northwestward, but turned north-northwestward the next day and slowed down as a midlevel ridge over Mexico weakened. Continuing slowly northward, the center of the depression made landfall very early on 7 July just west of Lazaro Cardenas, Mexico, with maximum winds of about $30 \mathrm{kt}$, and the circulation dissipated inland over mountainous terrain a few hours later. Heavy rains were reported at isolated locations along the coast of Mexico, including $140 \mathrm{~mm}$ at Manzanillo, but no casualties, floods, or other significant impacts were reported.

Tropical Depression Seventeen-E was another shortlived system that brought rain to the southwestern coast of Mexico while the center remained well offshore. It originated from a region of convection that developed south of the Gulf of Tehuantepec on 20 October, in association with a slow-moving tropical wave. This wave crossed Central America into the eastern Pacific on 1516 October. The convection associated with the wave became more persistent on 22 October and it is estimated 
TABLE 3. Homogenous comparison of official and CLIPER5 track forecast errors in the eastern North Pacific basin for the 2008 season for all tropical cyclones. Averages for the previous 5-yr period are shown for comparison.

\begin{tabular}{|c|c|c|c|c|c|c|c|}
\hline & \multicolumn{7}{|c|}{ Forecast period $(\mathrm{h})$} \\
\hline & 12 & 24 & 36 & 48 & 72 & 96 & 120 \\
\hline 2008 mean OFCL error (n mi) & 30.9 & 47.5 & 63.7 & 78.0 & 107.6 & 138.8 & 161.4 \\
\hline 2008 mean CLIPER5 error ( $\mathrm{n} \mathrm{mi)}$ & 40.8 & 72.9 & 110.7 & 148.3 & 207.2 & 245.8 & 283.6 \\
\hline 2008 mean OFCL skill relative to CLIPER5 (\%) & 24 & 34 & 42 & 47 & 48 & 43 & 43 \\
\hline 2008 mean OFCL bias vector $(\% \mathrm{n} \mathrm{mi})$ & $284 / 1$ & $201 / 2$ & $200 / 4$ & $214 / 6$ & $167 / 20$ & $142 / 47$ & $123 / 76$ \\
\hline 2008 No. of cases & 275 & 239 & 205 & 175 & 124 & 85 & 53 \\
\hline 2003-07 mean OFCL error ( $\mathrm{n} \mathrm{mi)}$ & 31.9 & 55.1 & 77.4 & 97.9 & 136.2 & 180.1 & 226.1 \\
\hline 2003-07 mean CLIPER5 error (n mi) & 38.5 & 75.4 & 115.5 & 153.2 & 222.4 & 279.7 & 340.4 \\
\hline 2003-07 mean OFCL skill relative to CLIPER5 (\%) & 17 & 26 & 32 & 36 & 38 & 35 & 33 \\
\hline 2003-07 mean OFCL bias vector $(\% / \mathrm{mi})$ & $311 / 3$ & $300 / 6$ & $298 / 11$ & $299 / 18$ & $296 / 19$ & $310 / 18$ & $317 / 25$ \\
\hline 2003-07 No. of cases & 1282 & 1129 & 979 & 849 & 620 & 439 & 293 \\
\hline 2008 OFCL error relative to $2003-07$ mean (\%) & -3 & -14 & -18 & -20 & -21 & -23 & -29 \\
\hline 2008 CLIPER5 error relative to $2003-07$ mean (\%) & 6 & -3 & -4 & -3 & -7 & -12 & -17 \\
\hline
\end{tabular}

that a tropical depression formed around 0600 UTC 23 October, centered about $410 \mathrm{n}$ mi south of Manzanillo.

The depression initially moved northward around the western periphery of a mid- to upper-level ridge, and southeasterly wind shear displaced the deep convection to the northwest of the low-level center. By early on 24 October, the depression turned toward the northwest, and southwesterly vertical wind shear increased with the approach of a mid- to upper-level trough. The strong wind shear displaced the deep convection well to the northeast of the low-level center, bringing some rainfall to the southwestern coast of Mexico. By 1800 UTC that day, the low-level center became ill-defined and void of deep convection because of the strong wind shear, and the depression degenerated into a remnant low when it was centered about $245 \mathrm{n}$ mi south-southwest of Manzanillo. The remnant low tracked west-northwestward for about a day, then moved westward until dissipation around 0000 UTC 28 October, about $600 \mathrm{n} \mathrm{mi}$ southwest of the southern tip of the Baja California peninsula.

\section{Forecast verification}

For all operationally designated tropical or subtropical cyclones in the Atlantic and eastern North Pacific basins, the NHC issues an official forecast of the cyclone's center position and maximum 1-min surface wind speed. Forecasts are issued every $6 \mathrm{~h}$ and contain projections valid at $12,24,36,48,72,96$, and $120 \mathrm{~h}$ after the forecast's nominal initial time $(0000,0600,1200$, or 1800 UTC). At the conclusion of the season, forecasts are evaluated by comparing the projected positions and intensities to the corresponding poststorm derived besttrack positions and intensities for each cyclone. A forecast is included in the verification only if the system is classified in the best track as a tropical or subtropical cyclone at both the forecast's initial time and at the projection's valid time. All other stages of development (e.g., tropical wave, remnant low, extratropical, etc.) are excluded. For verification purposes, forecasts associated with special advisories ${ }^{1}$ do not supersede the original forecast issued for that synoptic time; rather, the original forecast is retained. All verifications reported here include the depression stage.

A comparison of the average track errors for 2008 and the previous 5-yr period for the official forecasts and the 5-day version of the original Climatology and Persistence (CLIPER5; Neumann 1972; Aberson 1998) model forecasts is shown in Table 3, after Franklin (2009). CLIPER5 serves as a benchmark of track forecast skill. The 2008 NHC track errors were considerably lower than the 5-yr means at all forecast lead times and set records for accuracy from 24 to $72 \mathrm{~h}$. Biases of the mean track forecasts were generally small through $48 \mathrm{~h}$, with later periods showing a south and east bias through 120 h. The 2008 CLIPER5 track errors were lower than the 5-yr mean CLIPER5 errors at all forecast lead times, excluding 12 h, by $2 \%-16 \%$. This suggests that the 2008 eastern North Pacific tropical cyclones were easier to forecast than average. At all forecast lead times, the mean official track errors were substantially lower than the mean CLIPER5 errors indicating that the official forecasts were quite skillful.

Table 4, also adapted from Franklin (2009), compares official forecasts to the Decay and 5-day version of the Statistical Hurricane Intensity Forecast (SHIFOR5;

\footnotetext{
${ }^{1}$ Special advisories are issued whenever an unexpected significant change has occurred or when U.S. watches or warnings are to be issued between regularly scheduled advisories. The treatment of special advisories in forecast databases has not been consistent over the years. The current practice of retaining and verifying the original advisory forecast began in 2005 .
} 
TABLE 4. Homogenous comparison of official and Decay-SHIFOR5 intensity forecast errors in the eastern North Pacific basin for the 2008 season for all tropical cyclones. Averages for the previous 5-yr period are shown for comparison.

\begin{tabular}{|c|c|c|c|c|c|c|c|}
\hline & \multicolumn{7}{|c|}{ Forecast period $(\mathrm{h})$} \\
\hline & 12 & 24 & 36 & 48 & 72 & 96 & 120 \\
\hline 2008 mean OFCL error $(\mathrm{kt})$ & 6.0 & 9.8 & 11.9 & 12.9 & 15.7 & 17.6 & 18.0 \\
\hline 2008 mean Decay-SHIFOR5 error $(\mathrm{kt})$ & 6.9 & 11.1 & 14.2 & 15.6 & 16.3 & 18.0 & 18.3 \\
\hline 2008 mean OFCL skill relative to Decay-SHIFOR5 (\%) & 13 & 11 & 16 & 17 & 3 & 2 & 1 \\
\hline 2008 OFCL bias $(\mathrm{kt})$ & 0.4 & 0.5 & -0.3 & -2.9 & -6.2 & -11.6 & -11.8 \\
\hline 2008 No. of cases & 275 & 239 & 205 & 175 & 124 & 85 & 53 \\
\hline 2003-07 mean OFCL error (kt) & 6.2 & 10.4 & 13.9 & 16.3 & 18.7 & 19.2 & 19.1 \\
\hline 2003-07 mean Decay-SHIFOR5 error $(\mathrm{kt})$ & 7.0 & 11.3 & 14.9 & 17.6 & 20.3 & 20.9 & 20.7 \\
\hline 2003-07 mean OFCL skill relative to Decay-SHIFOR5 (\%) & 11 & 7 & 6 & 7 & 7 & 8 & 7 \\
\hline 2003-07 OFCL bias (kt) & 0.9 & 2.2 & 3.2 & 3.0 & 3.7 & 2.0 & -1.2 \\
\hline 2003-07 No. of cases & 1282 & 1129 & 979 & 848 & 620 & 439 & 293 \\
\hline 2008 OFCL error relative to 2003-07 mean (\%) & -3 & -6 & -14 & -21 & -16 & -14 & -6 \\
\hline 2008 Decay-SHIFOR5 error relative to 2003-07 mean (\%) & -1 & -2 & -5 & -11 & -20 & -14 & -12 \\
\hline
\end{tabular}

Jarvinen and Neumann 1979; Knaff et al. 2003) model that serves as a benchmark of intensity forecast skill. Average official intensity forecasts errors were lower than the previous 5-yr means at all time periods. However, Decay-SHIFOR5 had errors below their 5-yr means by comparable amounts, suggesting an easier-to-forecast year than average. The official forecasts had a low bias beyond $24 \mathrm{~h}$, and these biases were quite large at 96 and 120 h. The NHC forecasts have typically shown a high bias in the past, so this year's bias is notably different than has been seen in previous years. The official forecasts through $48 \mathrm{~h}$ displayed some skill during 2008 since the mean forecast errors for the year were generally lower than the corresponding SHIFOR5 errors at the various forecast times. However, this forecast skill was not observed in the later periods ( $72-120 \mathrm{~h})$. Finally, it should be noted that although official intensity forecast errors for the eastern North Pacific have not changed appreciably during the past decade, forecast skill has increased slightly (Franklin 2009).

Acknowledgments. The cyclone summaries are based on tropical cyclone reports written by the authors and their NHC colleagues: Lixion Avila, Robbie Berg, Jack Beven, Michael Brennan, Daniel Brown, Jessica Schauer Clark, James Franklin, Richard Knabb, Stacy Stewart, Todd Kimberlain, and Jamie Rhome. Ethan Gibney of the I.M. Systems Group at the NOAA Coastal Services Center produced the track chart. Best-track data west of $140^{\circ} \mathrm{W}$ were furnished by the Central Pacific Hurricane Center.

\section{REFERENCES}

Aberson, S. D., 1998: Five-day tropical cyclone track forecasts in the North Atlantic basin. Wea. Forecasting, 13, 1005-1015.

Avila, L. A., and J. R. Rhome, 2009: Eastern North Pacific hurricane season of 2007. Mon. Wea. Rev., 137, 2436-2447.
Brennan, M. J., C. C. Hennon, and R. D. Knabb, 2009: The operational use of QuikSCAT ocean surface vector winds at the National Hurricane Center. Wea. Forecasting, 24, 621-645.

Brueske, K. F., and C. S. Velden, 2003: Satellite-based tropical cyclone intensity estimation using the NOAA-KLM series advanced microwave sounding unit (AMSU). Mon. Wea. Rev., 131, 687-697.

Demuth, J. L., M. DeMaria, and J. A. Knaff, 2006: Improvement of advanced microwave sounding unit tropical cyclone intensity and size estimating algorithms. J. Appl. Meteor. Climatol., 45, 1573-1581.

Dvorak, V.F., 1984: Tropical cyclone intensity analysis using satellite data. NOAA Tech. Rep. NESDIS 11, Washington, DC, 47 pp.

Franklin, J. L., 2009: 2008 National Hurricane Center forecast verification report. NHC, $71 \mathrm{pp}$. [Available online at http:// www.nhc.noaa.gov/verification/pdfs/Verification_2008.pdf.]

Hawkins, J. D., T. F. Lee, J. Turk, C. Sampson, F. J. Kent, and K. Richardson, 2001: Real-time internet distribution of satellite products for tropical cyclone reconnaissance. Bull. Amer. Meteor. Soc., 82, 567-578.

Herndon, D. C., and C. Velden, 2004: Upgrades to the UW-CIMSS AMSU-based tropical cyclone intensity estimation algorithm. Preprints, 26th Conf. on Hurricanes and Tropical Meteorology, Miami, FL, Amer. Meteor. Soc., 118-119.

Jarvinen, B. R., and C. J. Neumann, 1979: Statistical forecasts of tropical cyclone intensity for the North Atlantic basin. NOAA Tech. Memo. NWS NHC-10, 22 pp.

Knaff, J. A., M. DeMaria, B. Sampson, and J. M. Gross, 2003: Statistical, 5-day tropical cyclone intensity forecasts derived from climatology and persistence. Wea. Forecasting, 18, 80-92.

Neumann, C. B., 1972: An alternate to the HURRAN (hurricane analog) tropical cyclone forecast system. NOAA Tech. Memo. NWS SR-62, 24 pp.

Office of the Federal Coordinator for Meteorological Research, 2008: National Hurricane Operations Plan. FCM-P12-2008, 188 pp. [Available online at http://www.ofcm.gov/nhop/08/nhop08.htm.]

Olander, T. L., and C. S. Velden, 2007: The advanced Dvorak technique: Continued development of an objective scheme to estimate tropical cyclone intensity using geostationary infrared satellite imagery. Wea. Forecasting, 22, 287-298.

Peterson, T. C., and M. O. Baringer, 2009: State of the climate in 2008. Bull. Amer. Meteor. Soc., 90, S1-S196.

Simpson, R. H., 1974: The hurricane disaster potential scale. Weatherwise, 27, 169-186. 
Copyright of Monthly Weather Review is the property of American Meteorological Society and its content may not be copied or emailed to multiple sites or posted to a listserv without the copyright holder's express written permission. However, users may print, download, or email articles for individual use. 